\title{
Doctor - Patient Relationships in Marge Piercy's Woman on the Edge of Time and Simone de Beauvoir's A Very Easy Death
}

\section{Gönül Bakay}

This paper aims to examine the patient-doctor and nurse relationships in Simone de Beauvoir's A Very Easy Death and Marge Piercy's Woman on the Edge of Time. Published in 1964, A Very Easy Death is a moving and personal account of the final six months of Beauvoir's mother written from a relative's point of view. Marge Piercy's Woman on the Edge of Time is a classic work of speculative science fiction that deals with universal themes including love, madness morality as well as society, gender and class.

Woman on the Edge of Time raises several questions in the readers' minds regarding doctorpatient relationships, the conditions of asylums, the dangerous experiments the doctors perform on patients, the meaning of progress and whether there will be a return to the past to find peace and harmony. Connie is the protagonist of the novel and her life as a poor Chicana woman is depicted through her relationships with her two husbands and lovers. Her first husband is killed by the police in a street brawl. Her second husband, on the other hand, abuses her physically which causes her to run away. Her lover dies in a medical experiment in the prison. Connie gets into a fight with her niece Dolly's pimp Geraldo because he tries to convince Dolly to have an abortion. Dolly seeks protection in Connie's home. Connie hurts Geraldo who then has her committed into an asylum. Connie's story starts with her second institutionalization, but her past life is recounted through the use of flash backs. She was first intitutionalized because of her violent behavior towards her own daughter, Angelina.

Unfortunately, Connie has never had the chance to live the life she wanted to live. She goes to college for two years but is forced to drop out abruptly. Because she can't afford a typewriter, she tries to make some money by typing the papers of a white student. She then becomes pregnant by him and leaves college. She later meets a black saxophone-player and a pickpocket who dies after he accepts to take part as a guinea pig in an experiment in prison. Connie is devastated by these traumatic events and takes to drinking and drugs. Suffering under considerable mental distress, she hits her own child and is sent to prison. Her daughter, on the other hand, is sent to a foster home. To avenge himself on Connie who hits him, Geraldo secures the assistance of a doctor to put Connie in a mental hospital where she is diagnosed with schizophrenia. As Judith Kegan Gardner observes: "The pimp and the mad doctor thus stand as the two examplary villains of this society. Both profit from turning the private realms of sexuality and of mental fantasy into institutions of exploitation" (75).

This unfortunate event marks the beginning of Connie's life as a mental patient. In this context, her story also reveals the harsh conditions of the hospitals. In this environment, even the relatives of the patients collaborate with the doctors to keep the former imprisoned. Throughout her life, Connie had been abused by men. Her pregnancy was a result of rape and she becomes barren as a result of the experiments performed on her in the mental hospital. Through her portrayal of the horrible hospital conditions, Piercy encourages the reader to think deeply about Connie's so-called madness. Is Connie really mad or is it rather the societal conditions that frame her to blame for her demise? I would argue that Connie is considered 
mad because she does not display the conventional behaviours expected of women. As argued by Gilbert and Gubar in their seminal Madwomen in the Attic, Piercy believes that it is societal rules, norms and regulations that drive women mad.

While at the hospital, Connie enters a futuristic world where the conditions are very different. Mettapoisett is the community of the future. It is the size of a village and "the comunity lives in rural conditions where cows graze and pure vegetables are grown. It reminds Connie of the Mexican village" ( Rosenthal, Miriam 2). It is important to note that in this seemingly utopian world, madness seems to be perceived as a natural part of life. Children are seen as belonging to the community. Births are controlled. A child is allowed to be born when someone dies... The state of madness is treated very differently in Mattapoisett. Luciente, who not only represents but also explains the future, says:

"our mad houses are places where people retreat when they want to go into themselves.-to collapse away on, see visions, hear voices of prophecy, bang on the walls, , relive in infancy,-getting in touch with the buried self and the inner mind.We loose part of ourseves, We all make choices that go bad... How can another person decide that it is time for me to disintegrate, to reintagrate himself?"( 60)

In the hospital the experiments performed on Alice Blue Bottom, show how women, especially unprotected women could be used as guinie pigs. Although Alice is a happy woman, the device doctors place in her her in order to control her drives her insane. Doctors don't really care about their patients; they are primarily interested in them as test subjects. During an experiment on Alice, a doctor observes with indifference:

You see we can electrically trigger almost every mood and emotion- the fight or flight reaction,euphoria,calm,pleasure,pain, terror,!We can monitor and induce reactions through the micro miniaturized radio under the skull. We believe through this procedure, we can control Alice's violent attacks and maintain her in a balanced state. The radio will be feeding information and telemetry straight into the computer once we are in the institute and Alice will be able to walk around the ward freely (204)

Piercy also implies that the loss of mental balance may have some seemingly positive consequences. By going deep within herself, the individual can discover her latent talents. Because they can not come into terms with their son's homosexuality, Skip's family send him to the mental hospital, hoping they can change him there. But Skip doesn't change in the way that is expected of him and eventually commits suicide. On the other hand, his counterpart in the futuristic world, Jackrabbit is accepted and loved for who he is. In this sense, Piercy draws attention to the fact that in this futuristic world, difference is not suppressed or punished but welcome.

It is important to note that Piercy does not completely see this future world she created as a utopia. Still, her ideas reflect the ideals espoused by proponents of feminism. Due to her suffering in life, Connie eventually loses her mental balance. The medicine she takes hinder her from thinking in a healthy way. She accepts giving her daughter for adoption without really thinking about the consequences. In the end, she tries to take revenge by poisoning the doctors.

The critic Richard Mc Carthy asks whether the Future World Connie visits is real or the product of the imagination of a mad woman. In his words: "My argument is, I'm afraid to say,that the utopian future that Connie experiences in Mattapoissett is a product of her psychosis, a fantasy that she uses to escape from the confines of the mental hospital and also a means to justify her final actions" (p. 3). Laing observes that people seek shelter in a fantasy world when things 
become unbearable. In his words: "The self avoids being related directly to real persons but relates itself to itself and to the objects which itself posits. The self can relate himself with immediacy to an object which is an object of its own imagination or memory but not a real person" (86).

Connie's experiences in the ward are vividly described: "She laid tied with strapped to a bed, staring at the bare bulb, shot up with meds. Thorazine, it felt worse, heavier. A massive dose. Hospital tranks hit her like a bulldozer when she taken nothing for a long time (16-17) [...]) All of her ached. Geraldo and his carnal Slick had beaten her twice.;once right after she had broken Geraldo's nose,and again on the way to Bellvue in his car" (17).

At times, she also feels there is no hope for her. Connie observes: "Surely, she would die here. Her heart would beat more and more slowly and then stop, like a watch running down. She stared at the room, empty except for the matress and odd stains, names, dates, word scratched somehow into the wall with blood, fingernails, pencil stubs, shit: how did she come to be in this desperate place?" (60) Laing refers to this kind of experience as petrification and depersonalization. He observes: "The dread of this happening: the dread, that is, of possibility of turning, or being turned, from a live person into a dead thing, into a stone, into a robot, an automaton without personal autonomy of action, an it without subjectivity" (46).

Fancourt observes that in this novel, Piercy disrupts constructed notions of sanity and insanity, arguing that madness is a gendered construct in patriarchal society, exploited by those in power and used as a means of oppression" (quoted in Yla- Kapee 260): “... Luciente views madness in the Langian manner as a possibility of mental growth" (Yla- Kapee, 261). In Connie's world, the doctors consider themselves "sane" and hence believe they have the right to pass judgement on patients they deem "mad". Laing observes: "I suggest, therefore, that sanity or psychosis is tested by degree of conjunction betwen two persons where the one is sane by common consent. The critical test of whether or not a patient is psyhotic is a lack of congruity an incongruity, a clash between him and me" (36).

Connie tries to resist the doctors but can do nothing. Doctors say: "Connie you are resisting. You are the patient. You know why you are here. The more you resist, the more you punish yourself. Because when you fight us, we can't help you" (261-262). "This is a Laingian double bind: either one resists and is treated like a subjugated person, - a patient- or one does not resist, and one is still treated like a subjugated person - a patient" ( Yla-Kapee, 271).

Connie is then selected for a scientific experiment. Doctors intend to put an implant in her brain which they believe will control Connie's nervous outbursts. Connie tries to resist this experiment and tries to escape from the asylum but fails to do so. Because she can not escape, she poisons the doctors who intend to operate on her. The book does not offer a neat satisfying ending - as in life there are very few clear-cut endings to stories. Connie is poor, hispanic, and lives on the periphery of society. Was Connie mad? Or were the people in her environment insane? The novel leaves this as an open ended question.

In brief, one can observe that, by shifting the narrative back and forth in time and connecting the present, past and the future, Piercey aims to show the interrelatedness of these time periods. In doing that, her main aim is to draw attention to the oppression and subjugation of women in our world. Feeling trapped in this hostile environment, the main character suffers from alienation and mental disorder. She is then labelled as "mad" by the very same forces that have driven her "insane". In this sense, her so-called descent into "madness" can be perceived as a defence mechanism, as a manifestaiton of her desire to find a space within which she can 
find safety and fulfillment. Even though this fantasy world might be a work of her creative imagination, it is more real to her than the real World which has offered her nothing but pain and suffering.

Simone de Beauvoir's A Very Easy Death recounts the last six weeks of her mother's life before she dies from cancer. The events she depicts belong to the period before the modern palliative care movement. Baeauvoir's mother was 78 when she was operated for cancer of the intestines. Prior to her operation she was complaining of anorexia and pain in her stomach. One day she collapses in her home and taken to the hospital. She is diagnosed as having sercoma and later develops bowel obstruction, peritonis, and ruptured viscus. She has an operation, puss drained and tumour removed. She dies four weeks later.

In a profoundly moving and powerful narrative, de Beauvoir depicts the condition of her mother, her feelings, the helplessness of her two daughters and the conduct of the doctors and the nurses. Throughout her account, she also draws attention to the loneliness of her mother and how the terminally ill people suffer from loneliness because no one can share their feelings. Laing says: "the isolation of the self is a corollary, therefore, of the need to be in control"(The Divided Self, 83) Several doctors are involved in her treatment and they display different attitudes in their conduct. When she first collapses in her home, a doctor living in the same apartment helps her. Later, when the family wants her personal local doctor to treat her, he refuses this request, saying that he wasn't called at the first instance. An appalled neighbour remarks: "after the shock and after her night in the hospital, your mother needed comforting by her usual doctor. He wouldn't listen to a word of it" (12).

Two doctors in particular are depicted in detail in the book: Dr P and Dr. $\mathrm{N}$ whose general attitudes and communication styles are very different. Dr N, a resuscitation expert, is desribed as quite cool and unemotional. Both Beauvoir and her sister try to talk with the doctor, urging him to act in such a way as to ensure that their mother won't suffer much. Poupette, Beauvoir's sister says "what's the good of tormenting her, if she s dying? Let her die in peace" (25). Beauvoir also speaks with this doctor she desribes as "white coat, white cap : a young man with an unresponsive face" She asks the doctor: "Why this tube, why torture Maman since there is no hope?" he answers: "I am doing what has to be done... At dawn she had four hours left, I have brought her back to life." "For what?" Beauvoir muses (25). When she opens her eyes and has a glassy look, Beauvoir thinks this may be the end. But the doctor $\mathrm{N}$ answers in a half pitying, half triumphant tone: "No, she has been revived too well for that" (78). Beauvoir observes that "for him she was the subject of an interesting experiment, not a person" (page no). He keeps his cool detached manner when Beuvoir's mother asks him for more injections to stifle the pain. He answers in a sardonic tone: "Ha, ha, you are going to be a real drug- addict. I can supply you with morphia at very interesting rates" (79). Then his expression hardens and he adds looking towards Beauvoir's direction: “There are two points upon which a self respecting doctor does not comprimise-drugs and abortion" (79).

Beuvoir observes that it is important for a doctor to care and feel empathy with for his patients. As Laing correctly observes : "To look and to listen to a patient and to see 'signs' of a disease and to look and listen to him simply as a human being are to see and to hear in as radically different ways as one sees, first the vase, then the faces in the ambigious Picture" (the divided self,33)

Dr. P, on the other hand, is depicted as having a more warm and caring personality. Beauvoir desribes him with the words: "I liked Dr. P. He did not assume consequential airs; he talked to Maman as though she was a human being and he answered my questions willingly" (82). When 
asked by the daughters whether their mother will be given enough doses when she suffers from excrutiating pain, he answers: "She will not suffer. She will be given the doses that are called for" (82). Beauvoir remarks that this doctor gave them confidence and made she and her sister feel calmer.

The book also deals with the conduct of the nurses and how this affects the paients. Due to the hard work they do, the nurses' often felt physically and mentally strained and thus their behaviour could sometimes upset the patients. Beauvoir notes that the elderly nurses in have more compassion. When doctors decide to operate on Beauvoir's mother after the consultation, Mme Gontrand, an elderly nurse, bursts out: "don't let her be operated on" then she clasps her mouth with her hand and says: "If Dr N knew I had said that to you! I was speaking as if it were my own mother" (26). When Beavoir asks her what will happen if they do operate on her, she refuses to give an answer. One of the nurses, Mademoiselle Laurent who had come to inquire after her in the evening gives her strength, helps her to spit, and massages her. Beauvoir comments: "Afterwards Maman looked at her with a real smile, -the first for four days" (41).

Beauvoir's mother also experiences real difficulty with defecation. The nurses try to put her on to a bed-pan but because she has nearly no flesh left Beauvoir feels as if they are setting her on knife-edges. Beavoir observes "the two women urged her, pulled her about, and the red haired nurse was rough with her" (48). Beauvoir goes out of the room with the nurses and tells them to allow her to defecate in her bed. One of the nurses says it is very humiliating for the patients, the other says "she will be soaked it is very bad for the bed sores" (page no). Beauvoir tells them that they can change the clothes at once. When she returns to her mother's side her mother moans: "The red-haired one is an evil woman" (48).

When the end comes, Beauvoir's sister Poupette sobs:" the doctors said she would go out like a candle: it wasn't like that, it wasn't like that at all" (78). "But, Madame, replies the nurse, I assure you, it was a very easy death" (78).

The problem of palliative care continues in our day. There is also heated debate on whether in terminal cases the patient should be told the truth or not. Some doctors believe that the patient has the right to know the truth and that he may want to put his affairs in order. There are others who believe that one does not have the right to destroy the last ray of hope. Most of the cancer patients who retain their faculties somehow understand and feel that the end is near. Yet, they still don't want to acknowledge it to themselves and their loved ones. I remember a cancer patient saying: "I feel perfectly allright. They are telling me that I have cancer. The diagnosis must be wrong". The patient was at the fourth stage of cancer of the intestines and yet he felt perfectly all right. He had gone to the doctor because he complained of a slight pain in the abdoman area.It was only a month prior to his death that he accepted that the diagnosis must be true.

The ones that are left behind always blame themselves for acting or not acting in various ways. Sometimes the doctors ask the closest relatives do decide for the patient: should they tie him to a breathing machine or let him die in peace. Or in the case of an elderly patient with a heart condition if there is one percent chance of his surviving an operation, should he be left to die in peace or operated on depending on that one pecent chance. I personally had to decide for two such patients and I always opted for them being given the chance to live until the last moment. Knowing these peoples' characters I knew, they would want to live even if the chances were very low. They would want to take this chance. Of course, this leaves the surviving ones with a clear conscience but is it really the best decision for the suffering patients? That is debatable. 
Beauvoir gives a detailed account of her feelings after her mother's death. She observes: "What would have happened if Man's doctor had detected the cancer as early as the first symtoms? N doubt it would have been treated with rays and Maman would have lived two or three years longer. But she would have known or at least suspected the nature of her disease, and she would have passed the end of her life in a state of dread. What we bitterly regreted was that the doctor's mistake had deceived us; otherwise Maman's happiness would have been our main concern. I should have seen more of her: I should have invented things to please her" (82).

Beauvoir also identifies with the terminally ill and their feelings. She observes: "In public wards, when the last hour is coming near, they put a screen round the dying man's bed; he has seen this screen round other beds that were empty the next day; he knows" (83).

How can the relationship between doctors, nurses and the patients can be improved? What more can be done? I think support groups formed of psychologists can give support to both the patients and close ones who take care of the patient. Many stress that those who are close to the patient should be provided with psychologial support more than the patient, because they doubly suffer both personally and also for the terminally ill one. Medical humanities studies is also a positive step in this direction towards establishing stronger empathy between the doctor and the patient.

Beauvoir observes that before she was confronted with the death of her mother, she would have considered anyone weeping for a close one dead at seventy or eighty to be neurotic. That was a perfectly right age to die.. Beauvoir, comments that despite appearances one is alone in death She observes: “Even when I was holding Maman's hand, I was not with her. There is no such thing as a natural death: nothing that happens to a man is natural, since his presence calls the World into question. All men must die: but for every man his death is an accident and even if he knows it and consents to it, an unjustifiable violation" (92).

\section{Works Cited}

Beauvoir, Simone, A Very Easy Death Harmondsworth, :Penguin Books Ltd.1969.

Laing,R.D The Divided Self.Hamondsworth: Penguin books,1959.

Laing, R.D. Sanity,Madness and the FamilyLondon:Tavistock publications, 1964

Michael, Cornier Magali.Feminism and the Postmodern Impulse New York: State University of New York Press,1996.

O’Byrne,D.M. “Marge Piercy's Non -Utopia in Women on Edge of Time” Leicestershire: Five Leaves Publications,2012.

Piercy, Marge. Women on The Edge of Time London: The Women' Press, 1979.

Shands, Kerstin.W. The Repair of the World: The Novels of Marge Piercy, Westport: Greenwood Press, 1994.

Yla-Kapee, Annina. Telling Madness: Narrative,Diagnosis Power and Literary Theory Tempere univerity press, 2014. 